\title{
Antimicrobial activity against oral pathogens and immunomodulatory effects and toxicity of geopropolis produced by the stingless bee Melipona fasciculata Smith
}

Silvana A Liberio ${ }^{1,2+}$, Antônio Luís A Pereira², Richard P Dutra ${ }^{1,4}$, Aramys S Reis ${ }^{1}$, Maria José AM Araújo ${ }^{1}$, Nadia S Mattar', Lucilene A Silva ${ }^{1}$, Maria Nilce S Ribeiro ${ }^{4}$, Flávia Raquel F Nascimento ${ }^{1,3}$, Rosane NM Guerra ${ }^{1,3+}$ and Valério Monteiro-Neto $3,5^{*}+$

\begin{abstract}
Background: Native bees of the tribe Meliponini produce a distinct kind of propolis called geopropolis. Although many pharmacological activities of propolis have already been demonstrated, little is known about geopropolis, particularly regarding its antimicrobial activity against oral pathogens. The present study aimed at investigating the antimicrobial activity of $M$. fasciculata geopropolis against oral pathogens, its effects on S. mutans biofilms, and the chemical contents of the extracts. A gel prepared with a geopropolis extract was also analyzed for its activity on $S$. mutans and its immunotoxicological potential.
\end{abstract}

Methods: Antimicrobial activities of three hydroalcoholic extracts (HAEs) of geopropolis, and hexane and chloroform fractions of one extract, were evaluated using the agar diffusion method and the broth dilution technique. Ethanol $(70 \%, \mathrm{v} / \mathrm{v})$ and chlorhexidine $(0.12 \%, \mathrm{w} / \mathrm{w})$ were used as negative and positive controls, respectively. Total phenol and flavonoid concentrations were assayed by spectrophotometry. Immunotoxicity was evaluated in mice by topical application in the oral cavity followed by quantification of biochemical and immunological parameters, and macro-microscopic analysis of animal organs.

Results: Two extracts, HAE-2 and HAE-3, showed inhibition zones ranging from 9 to $13 \mathrm{~mm}$ in diameter for S. mutans and C. albicans, but presented no activity against L. acidophilus. The MBCs for HAE-2 and HAE-3 against $S$. mutans were $6.25 \mathrm{mg} / \mathrm{mL}$ and $12.5 \mathrm{mg} / \mathrm{mL}$, respectively. HAE-2 was fractionated, and its chloroform fraction had an MBC of $14.57 \mathrm{mg} / \mathrm{mL}$. HAE-2 also exhibited bactericidal effects on $\mathrm{S}$. mutans biofilms after $3 \mathrm{~h}$ of treatment. Significant differences $(p<0.05)$ in total phenol and flavonoid concentrations were observed among the samples. Signs toxic effects were not observed after application of the geopropolis-based gel, but an increase in the production of IL-4 and IL-10, anti-inflammatory cytokines, was detected.

Conclusions: In summary, geopropolis produced by M. fasciculata can exert antimicrobial action against S. mutans and C. albicans, with significant inhibitory activity against S. mutans biofilms. The extract with the highest flavonoid concentration, HAE-2, presented the highest antimicrobial activity. In addition, a geopropolis-based gel is not toxic in an animal model and displays anti-inflammatory effect.

\footnotetext{
* Correspondence: valerio.monteiro@ceuma.br

† Contributed equally

${ }^{3}$ Laboratório de Microbiologia, Universidade Federal do Maranhão, Av. dos

Portugueses, SN, CEP: 65.080-040, São Luís, Maranhão, Brazil

Full list of author information is available at the end of the article
} 


\section{Background}

Propolis is a generic name used for the product that results from the addition of the mandibular secretions of various bee species to resins these insects collect from the buds, flowers and exudates of different plants [1]. Distinct pharmacological activities of propolis have been demonstrated, including antimicrobial, anti-inflammatory, antitumor, cytotoxic, hepatoprotective and immunomodulatory properties, among others [2-4]. This diversity of pharmacological activities is related to quantitative and qualitative variations in the composition of different propolis samples [5,6].

Known pharmacological activities generally refer to propolis produced by Apis mellifera, the most common bee species in many countries and the main producer of honey in those countries [7]. However, some of these activities have also been observed in propolis produced by other bee species, including members of the tribe Meliponini [6,8]. Meliponines are stingless bees native to tropical and subtropical regions [9]. In the north and in some states of northeastern Brazil, Melipona compressipes fasciculata is the most important species for honey bee production and play an important role in flower pollination [10]. Stingless bees generally mix resinous material that they collect from plants with wax and soil and store large deposits of this material, called geopropolis, inside their hives. The final product is then used in a similar manner as propolis produced by $A$. mellifera [11].

In some countries, geopropolis has been used empirically by the population for wound healing, for the treatment of gastritis, and as an antibacterial agent [12]. Studies of ethanolic extracts of geopropolis produced by $M$. compressipes and M. quadrifasciata anthidioides have demonstrated its antimicrobial activity [13].

Although recent studies of $M$. quadrifasciata geopropolis have shown inhibitory activity against Gram-negative bacteria [14], this activity seems to be more pronounced against Gram-positive bacteria $[6,8]$. These results may be correlated with variations in chemical content, as has been observed for other types of propolis $[13,15]$.

Due to its inhibitory effects on cariogenic microorganisms, such as Streptococcus mutans and Lactobacillus spp., and on bacterial enzymes (glucosyltransferases) involved in the cariogenic process, A. mellifera propolis has been proposed as an adjuvant for the control or prophylaxis of infectious diseases of the oral cavity, particularly dental caries [16-20].

Besides the pharmacological properties of propolis, its addition to different commercial products has drawn the attention of researchers for its possible toxicity, such as the triggering of hypersensitivity in the user. Most results show that the use of Apis propolis is relatively safe, since it presents low toxicity [21-25].

Thus, the objective of the present study was to investigate the antimicrobial activity of $M$. fasciculata geopropolis extracts against oral pathogens, its effects on the viability of $S$. mutans biofilms, and the chemical contents of the extracts. A gel prepared with a geopropolis extract was further analyzed for its antimicrobial activity on S. mutans and its immunotoxicological potential.

\section{Methods}

\section{Preparation and fractionation of geopropolis extracts}

Samples of geopropolis produced by M. fasciculata were collected from bee hives located in the municipalities of Palmeirândia and São Bento, a microregion of the Western Lowland of Maranhão (2 $\left.2^{\circ} 37^{\prime} 30^{\prime \prime S} 44^{\circ} 52^{\prime} 30^{\prime \prime W}\right)$, the ecosystems of which include mangrove swamps, floodplains, lakes, and babassu palm forests, and in the municipality of Fernando Falcão, a microregion of Alto Mearim and Grajaú (6 $\left.6^{\circ} 30^{\prime \prime S} 44^{\circ} 52^{\prime} 30^{\prime \prime W}\right)$, a savannah area. These municipalities are situated in the northwestern and central region of the State of Maranhão, in northeastern Brazil.

Individual geopropolis samples were weighed and mixed with ethanol $(70 \%, \mathrm{v} / \mathrm{v})$ to a final proportion of geopropolis/ethanol of 30/70 (w/v). Next, the samples were triturated in a homogenizer and macerated for 48 $h$. The samples were then filtered through filter paper to remove the inorganic portion (soil), concentrated in a rotary evaporator and air-dried at $40^{\circ} \mathrm{C}$ for $48 \mathrm{~h}$. The three hydroalcoholic extracts obtained (HAE-1, HAE-2 and HAE-3) were stored in a refrigerator $\left(4-8^{\circ} \mathrm{C}\right)$ until the time of analysis. The crude extract presenting the highest activity, HAE-2, was fractionated by liquid/liquid partitioning using solvents of different polarities (hexane and chloroform) [26]. The fractions obtained, HAE-2HF (hexane fraction) and HAE-2-CF (chloroform fraction), were concentrated, dried and stored as described above.

\section{Preparation of a geopropolis-based gel}

A geopropolis-based gel was prepared by mixing HAE-2 with $70 \%(\mathrm{w} / \mathrm{v}) \mathrm{Natrosol}^{\circledR}$ and 30\% (v/v) propylenoglicol, as vehicle, for the formulation of a $5 \%(\mathrm{w} / \mathrm{w})$ gel. Patent pending under No. PI0905583-5 INPI-RIMA, Brazil.

\section{Animals}

C57Bl/6 mice, weighting 25-35 g, from the Central Animal Facility of the Federal University of Maranhão were used in the experiments with the geopropolis gel. The study was approved by the Ethics Committee for Animal Studies of the State University of Maranhão (No. 010/ 2007). All animals were cared for in accordance with 
the guidelines of the Brazilian Council of Animal Studies.

\section{In vitro evaluation of antimicrobial activity}

Antimicrobial activity was evaluated using the agar diffusion method. For this study, $25 \mu \mathrm{L}$ of extract was added to wells ( $5 \mathrm{~mm}$ in diameter) in agar plates as described previously [27]. The following culture media were used: brain-heart infusion agar (BHI agar, Difco) for S. mutans, Rogosa agar (Difco) for Lactobacillus acidophilus, and Sabouraud dextrose agar (Difco) for Candida albicans. Twenty-four-hour cultures of $S$. mutans (ATCC 25175), L. acidophilus (ATCC 4356) and C. albicans (ATCC 18804) were used. Cultures were adjusted with sterile saline to a density equivalent to the McFarland scale No. $0.5\left(10^{8} \mathrm{CFU} / \mathrm{mL}\right)$ and inoculated onto agar plates with a sterile swab. Ethanol $(70 \%, v / v)$ and an aqueous solution of chlorhexidine gluconate $(0.12 \%, \mathrm{w} / \mathrm{w})$ were used as negative and positive controls, respectively. Plates of S. mutans and L. acidophilus were incubated at $37^{\circ} \mathrm{C}$ for $48 \mathrm{~h}$ in $5 \% \mathrm{CO}_{2}$. C. albicans plates were incubated under aerobic conditions at $37^{\circ} \mathrm{C}$ for $24 \mathrm{~h}$. After incubation, the diameters of the zones of inhibition were measured.

The minimum bactericidal concentrations (MBCs) were determined by the broth dilution technique using BHI broth (Difco). The final concentrations of tested hydroalcoholic extracts ranged from 12.5 to $0.19 \mathrm{mg} / \mathrm{mL}$ except the chloroform fraction (HAE-2-CF) for which concentrations ranged from 20 to $0.9 \mathrm{mg} / \mathrm{mL}$. All assays were carried out in duplicate in three independent experiments. Dilutions of hydroalcoholic extracts were streaked on BHI agar plates and the $\mathrm{MBC}$ was determined. The MBC was defined as the lowest concentration of the extract that inhibited bacterial growth [28].

The minimum inhibitory concentration (MIC) for the geopropolis-based gel, against S. mutans (ATCC 25175), was determined by the broth dilution technique using BHI broth (Difco). The final concentrations of the product varied from 50 to $3.12 \mathrm{mg} / \mathrm{mL}$ and the minimum bactericidal concentration $(\mathrm{MBC})$ was determined as described above.

\section{Inhibition of biofilm viability}

The effect of HAE-2 on the viability of $S$. mutans (ATCC 25175) biofilms was evaluated as described previously $[29,30]$, with some modifications. Briefly, for biofilm production, 24-well polystyrene cell-culture plates (TPP, Zellkultur und Labortechnologie, Switzerland) containing $1 \mathrm{~mL}$ tryptone-yeast extract broth supplemented with $1 \%$ sucrose were inoculated with approximately $1 \times 10^{6} \mathrm{CFU} / \mathrm{mL}$ of $S$. mutans. The culture medium was changed daily. On the fourth day, the culture supernatant was removed by aspiration, the bacterial biofilm was treated with HAE-2 diluted in 1\% peptone broth at a concentration corresponding to four times its $\mathrm{MBC}(25 \mathrm{mg} / \mathrm{mL})$, and bacterial counts were evaluated at different intervals. The negative control well contained only $1 \%$ peptone broth and chlorhexidine $(0.12 \%)$ was used as the positive control [31]. The treatment solution was removed by aspiration at 1-h intervals for $4 \mathrm{~h}$, and the biofilm was gently washed three times with phosphate-buffered saline (PBS), $\mathrm{pH}$ 7.2, scraped off, and suspended in $1 \mathrm{~mL} 1 \%$ peptone broth. The suspension was sonicated twice in a Model T7 sonicating water bath (Thornton, Brazil) at $50 \mathrm{~W}$ with three pulses of $10 \mathrm{~s}$ each at intervals of $5 \mathrm{~s}$ [30]. After homogenization, the suspension was diluted from $10^{-1}$ to $10^{-4}$ in PBS. Aliquots ( $100 \mu \mathrm{L}$ of each dilution) were spread onto blood agar plates (blood agar base containing 5\% sheep blood) and incubated in a $5 \% \mathrm{CO}_{2}$ atmosphere at $37^{\circ} \mathrm{C}$ for $48 \mathrm{~h}$. After incubation, CFU $/ \mathrm{mL}$ were determined. These data were $\log _{10}$ transformed for analysis. All assays were carried out in quadruplicate.

A bactericidal effect was attributed to geopropolis extract when it resulted in a reduction of $\geq 3 \log _{10}$ $\mathrm{CFU} / \mathrm{mL}$ above baseline [30].

\section{Chemical characterization}

Phenolic compounds, triterpenes and alkaloids were assayed in all extracts as described previously [32-34]. Total phenol concentration was assayed by spectrophotometry with the Folin-Ciocalteau reagent (Merck, Brasil) and $20 \%$ sodium carbonate solution for $2 \mathrm{~h}$ at room temperature in the dark. Known concentrations of gallic acid were used as standards. Measurements were made in a spectrophotometer (Cary 50 UV-VIS, Agilent, USA) at $760 \mathrm{~nm}$ and the results were expressed as a percentage of gallic acid [33]. The calibration equation for gallic acid (Sigma) was $\mathbf{y}=$ $0.06352 \mathbf{x}-0.06132\left(R^{2}=0.99\right)$ where $\mathbf{y}$ is absorbance and $\mathbf{x}$ is $\mathrm{mg} / \mathrm{mL}$ of gallic acid.

The concentration of total flavonoids was determined by spectrophotometry in $2 \%$ aluminum chloride for 30 min at room temperature in the dark. Known concentrations of quercetin were used as standards and measurements were made at $425 \mathrm{~nm}$. The results were expressed as a percentage of quercetin [33]. The calibration equation for quercetin (Merck) was $\mathbf{y}=0.07347 \mathbf{x}$ $0.00868\left(R^{2}=0.99\right)$ where $\mathrm{y}$ is absorbance and $\mathbf{x}$ is $\mathrm{mg} /$ $\mathrm{mL}$ of quercetin. After linear regression analysis (CI 95\%), both gallic acid and quercetin showed linear responses with different concentrations in the residue analysis. The relative standard deviations of the slopes were $\leq 5 \%$ for both standards (gallic acid, $\mathrm{n}=9$; quercetin, $\mathrm{n}=6$ ).

According to the Brazilian legislation, total phenols and flavonoids contents should be included in the 
chemical analysis as one of the quality criterion of propolis extracts [35].

The detection of triterpenes was performed by the Lieberman-Buchard reaction. Briefly, $2 \mathrm{~mL}$ of extract were mixed with $2 \mathrm{~mL}$ of chloroform. The mixture was filtered in the presence of $\mathrm{Na}_{2} \mathrm{SO}_{4}$ and $1 \mathrm{~mL}$ of acetic anhydride was added. After the addition of 3 drops of concentrated $\mathrm{H}_{2} \mathrm{SO}_{4}$, a change in color to brownish/red indicated the presence of triterpenes [32].

Total alkaloid content of extracts was determined using the Dragendorff's, Hager's, and Mayer's reagents [34]. Three aliquots of dried geopropolis extracts (10 $\mathrm{mg}$ ) were dissolved in $1 \mathrm{~mL}$ of distilled water that had been acidified to $\mathrm{pH} 2.0-2.5$ with $0.01 \mathrm{~N} \mathrm{HCl}$. Alkaloids were then investigated with 5 drops of each reagent separately in each tube.

\section{Animal experimental procedures}

The animals were divided in three groups of 6 animals each, as follows: saline (S) - received a topical application of a sterile $0.85 \% \mathrm{NaCl}(\mathrm{w} / \mathrm{v})$ solution; GS - received a topical application of the pure gel base; and GP - received the gel base with HAE-2. The gel was applied topically to the oral cavity of the mice $(25 \mu \mathrm{L} /$ application $)$, for a period of 1 minute, on four consecutive days.

\section{Assessment of biochemical parameters and cytokine production}

For the biochemical and immunological analysis, blood samples were collected from the retro-orbital plexus on the seventh day after treatment. The samples were transferred to conical plastic tubes, with or without EDTA, and centrifuged at $1500 \mathrm{rpm}$ for 10 minutes. Biochemical assessment consisted of a micro-assay to determine the serum concentrations of calcium, urea, cholesterol, triglycerides, albumin and glucose. The analysis were performed by means of automated procedures on an Architect - C8000 apparatus (Abbott ${ }^{\circledR}$ ), using reagents from Labtest (Brazil). The concentrations of IFN- $\gamma$, IL-4, TNF- $\alpha$ and IL-10 were determined by immunoenzymatic assay (enzyme-linked immunosorbent assay; ELISA), according to the manufacturer's instructions (eBiosciences). Recombinant cytokines were used to generate a standard curve. The limit for detection in the assay was $2 \mathrm{pg} / \mathrm{mL}$ for IFN- $\gamma$, TNF- $\alpha$, and IL-4, and $4 \mathrm{pg} / \mathrm{mL}$ for IL-10. The concentrations of cytokines were established using the coefficient of linear regression from values obtained on the standard curve.

\section{Macro- and microscopic assessment of the organs}

The macroscopic analysis of the tongue, spleen, liver, stomach, and kidney considered the following parameters: size, weight, integrity and presence or not of changes visually detectable. Only the tongue was not weighed. For the histopathological analysis, all organs were fixed in $10 \%$ formol and embedded in paraffin. Next, $5 \mu \mathrm{m}$ thick sections were cut on a microtome and stained with hematoxylin and eosin. The slides were examined in a light microscope with 20,40 and $100 \times$ objectives. The following parameters were analyzed: the presence of vascular congestion, edema, inflammatory infiltrate, and hemorrhage. Tissue changes were scored as: 0 for absent, 1 for scarce, 2 for moderate and 3 for intense.

\section{Statistical analysis}

The results were analyzed using SPSS for Windows 16.0 software (2007). Inhibition zones were compared using the Mann-Whitney test. Total phenol and flavonoid concentrations in the extracts as well as bactericidal effects of geopropolis on S. mutans biofilm viability were evaluated by analysis of variance (ANOVA) in conjunction with the Tukey multiple comparisons test. Data obtained with animals were expressed as mean \pm standard deviation $(\mathrm{X} \pm \mathrm{SD})$ for the immunological and biochemical results, and as mean \pm standard error for the histopathological data. Statistical analysis consisted of analysis of variance (ANOVA), followed by NewmanKeuls test. Organ weights were subjected to Tukey's test and the histopathological data were analyzed by unpaired and single-tailed Student's $t$-tests. For all tests, effects were considered significant when $\mathrm{p}<0.05$.

\section{Results}

Agar diffusion tests showed the antimicrobial action of geopropolis extracts (HAE-2 and HAE-3), with inhibition zones ranging from 10 to $13 \mathrm{~mm}$ for S. mutans and from 9 to $13 \mathrm{~mm}$ for $C$. albicans. No activity against $L$. acidophilus was detected (Table 1). HAE-2 and HAE-3

\section{Table 1 In vitro activity of geopropolis extracts against Streptococcus mutans, Lactobacilus acidophilus and Candida albicans}

\begin{tabular}{|c|c|c|c|}
\hline \multirow[t]{2}{*}{ Extracts $^{a}$} & \multicolumn{3}{|c|}{ Inhibition zone in $\mathrm{mm}(\bar{X} \pm \mathrm{SD})^{\mathrm{b}}$} \\
\hline & S. mutans & C. albicans & L. acidophilus \\
\hline HAE-1 & $0^{d}$ & $0^{d}$ & $0^{d}$ \\
\hline HAE-2 & $13 \pm 1^{\mathrm{cd}}$ & $13 \pm 3^{b}$ & $0^{d}$ \\
\hline HAE-3 & $10 \pm 2^{\mathrm{cd}}$ & $9 \pm 1^{c d}$ & $0^{d}$ \\
\hline HAE-2-CF & $13 \pm 2^{\mathrm{cd}}$ & $0^{d}$ & $0^{d}$ \\
\hline HAE-2-HF & $0^{d}$ & $0^{d}$ & $0^{d}$ \\
\hline Chlorhexidine $(0.12 \%)$ & $23 \pm 1$ & $15 \pm 2$ & $20 \pm 3$ \\
\hline Ethanol $(70 \%)$ & 0 & 0 & 0 \\
\hline \multicolumn{4}{|c|}{ a Extracts of geopropolis from different municipalities, as shown in Table 1.} \\
\hline \multicolumn{4}{|c|}{$\begin{array}{l}\text { d Significantly different from positive control }(0.12 \% \text { chlorhexidine) }(p<0.05 \text {; } \\
\text { Mann-Whitney test). }\end{array}$} \\
\hline
\end{tabular}


exhibited significant antimicrobial activity against $S$. mutans and $C$. albicans when compared to the negative control $(\mathrm{p}<0.05)$. HAE-1 showed no antimicrobial activity against the microorganisms tested.

Evaluation of the antimicrobial activity of HAE-2 fractions revealed that only the chloroform fraction showed an inhibition zone when tested against S. mutans (13 $\mathrm{mm})$. No antimicrobial activity of the hexane or chloroform fractions was observed against $C$. albicans. The MBC against $S$. mutans was $6.25 \mathrm{mg} / \mathrm{mL}$ for HAE-2, $12.5 \mathrm{mg} / \mathrm{mL}$ for HAE-3, and $14.5 \mathrm{mg} / \mathrm{mL}$ for the chloroform fraction HAE-2-CF. The MBC of geopropolisbased gel (prepared with HAE-2) against S. mutans was confirmed in $12.5 \mathrm{mg} / \mathrm{mL}$.

Since HAE-2 presented a lower MBC than the other extracts and since the pathogenesis of the cariogenic process is related to the formation of a dental biofilm, we investigated whether this extract was able to inhibit the viability of $S$. mutans biofilms. A significant reduction in CFU/mL was observed after $2 \mathrm{~h}$ exposure of a biofilm to geopropolis extract HAE-2 or chlorhexidine (Figure 1). However, bactericidal effects were observed after $3 \mathrm{~h}$ treatment with geopropolis extract (reductions higher than $3 \log _{10}$ were obtained). Chlorhexidine treatment resulted in total elimination of $S$. mutans after $3 \mathrm{~h}$ exposure to the biofilm.

Chemical characterization of the geopropolis extracts indicated the presence of phenolic compounds in all samples. There were significant differences $(p<0.05)$ in total phenol and flavonoid concentrations among the samples analyzed (Table 2). Phenol content differed among the three extracts studied, with the lowest concentration being observed in HAE-2. In contrast, this

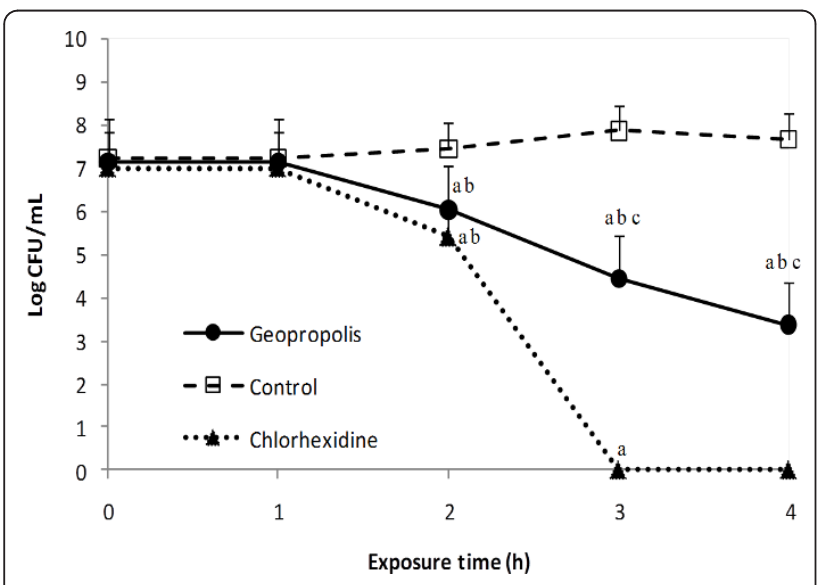

Figure 1 Bactericidal effects of HAE-2 on the viability of $S$. mutans biofilms. (a) $p<0.05$ Effects in relation to time 0 ; (b) $p<$ 0.05 Comparison of geopropolis activity on the biofilm viability in relation to the control ( $1 \%$ peptone broth) and (c) $p<0.05$ Comparison of geopropolis activity on the biofilm viability relative to chlorhexidine. Comparisons were analyzed using the Tukey test. extract contained the highest concentration of flavonoids. Triterpenes were detected in HAE-1 and HAE-2, but not HAE-3; alkaloids were not detected in any sample.

The experimental procedures with animals did not lead to any alteration in the serum concentration of calcium, albumin, and glucose in the GP group. On the other hand, animals in this group presented an increased concentration of urea and reduced concentrations of cholesterol, and triglycerides (Figure 2).

A significant increase in the production of IL-4 and IL-10 was observed in the GP group, while the production of IFN- $\gamma$ and TNF- $\alpha$ was kept unaltered when compared to the $\mathrm{S}$ and the GS groups (Figure 3).

No significant changes were observed in the body weight of the animals and also in relation to the organs weight, with the exception of the stomach in the GS group (Table 3 ). Besides, no macro- or microscopic alteration was detected in the liver, kidney, or stomach. However, histopathological alterations, such as: vascular congestion, presence of edema, inflammatory infiltrate, and hemorrhage in the animal tongues, were significantly greater in the GS and $S$ groups than in the GP group (Table 4).

\section{Discussion}

In this study we observed that geopropolis can display inhibitory effects on some oral pathogens, without detectable toxicity in mice. Furthermore, an immunomodulatory activity, due to an increased anti-inflammatory cytokines, was also detected.

The inhibitory activity displayed by geopropolis against $S$. mutans and $C$. albicans was previously observed in extracts and fractions obtained from Apis propolis [15-17,19,20,36,37]. However, none of the three geopropolis extracts tested in this study were seen to have antimicrobial activity against $L$. acidophilus, unlike propolis extracts [38].

The inhibitory activity of geopropolis against $S$. mutans and C. albicans, but not against L. acidophilus, corresponds with the clinical significance of these microorganisms in oral cavity diseases. Both S. mutans and $L$. acidophilus ferment carbohydrates, forming organic acids that promote decalcification of dental enamel and dentine. Thus, the presence of these microorganisms is frequently associated with dental caries $[39,40]$. S. mutans is responsible for the initial demineralization of dental enamel, whereas bacteria of the genus Lactobacillus are related to lesion progression, i.e., after the initiation of the caries process [41]. Therefore, we speculate that a product containing $M$. fasciculata geopropolis, which mainly acts on $S$. mutans, may have important implications for caries-prevention strategies because $S$. mutans growth and biofilm formation are required for the onset of dental caries. 
Table 2 Phenol and flavonoid concentrations of hydroalcoholic geopropolis extracts

\begin{tabular}{|c|c|c|c|}
\hline Extract & City & Total Phenol \% ( \pm SD) ${ }^{a, b}$ & Total Flavonoids $\%\left( \pm\right.$ SD) ${ }^{a, c}$ \\
\hline HAE-1 & Fernando Falcão & $67.4(2.0)^{d}$ & $1.07(0.04)^{f}$ \\
\hline HAE-2 & Palmeirândia & $14.6(2.3)^{\mathrm{e}}$ & $2.91(0.22)^{d}$ \\
\hline HAE-3 & São Bento & $51.2(3.9)^{f}$ & $1.11(0.01)^{f}$ \\
\hline
\end{tabular}

${ }^{a}$ Results are expressed as the average of assays carried out in triplicate.

${ }^{\mathrm{b}}$ Expressed as percentage of gallic acid.

c Expressed as percentage of quercetin.

$d$, e, f Values followed by different superscripts are significantly different from each other $(p<0.05$; Tukey test).

Little is known about the antibacterial and antifungal activities of geopropolis produced by native bees such as M. fasciculata, especially regarding its activities against oral microorganisms. A recent in vivo study showed that geopropolis produced by $M$. fasciculata promoted a reduction in salivary $S$. mutans counts [42]. However, the authors did not investigate the effects of geopropolis on other microorganisms, and no in vitro tests were performed. We found no other studies in the literature investigating the antimicrobial activity of geopropolis produced by $M$. fasciculata against $S$. mutans. Thus, the present findings are especially relevant since they underscore the potential for finding new active compounds that work against this microorganism in $M$. fasciculata geopropolis extracts.

The bactericidal activity of geopropolis extracts we observed against $S$. mutans biofilms is relevant not only because it confirms our in vitro results but also because it more closely reproduces the real conditions of the cariogenic process. Biofilm models are more relevant than studies which use planktonic cells because of the different growth of biofilm cells, their altered
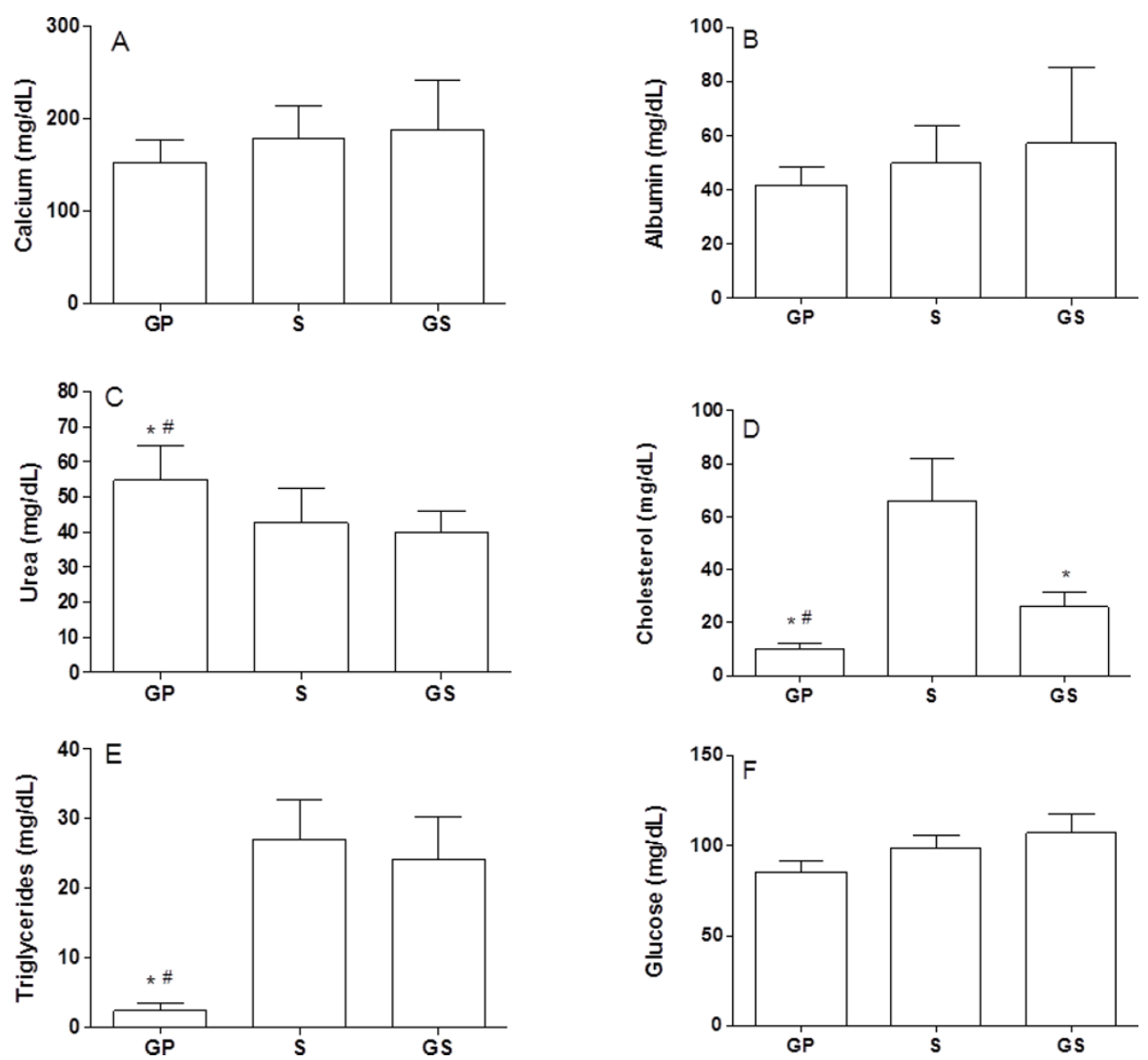

Figure 2 Biochemical assessment. Biochemical assessment of $(57 \mathrm{Bl} / 6$ mice submitted to topical oral treatment with gel containing propolis $(G P)$, compared to the group treated with the gel base (GS) or with saline (S). The serum concentrations of calcium (A); albumin (B); urea (C); cholesterol (D); triglycerides (E); and glucose (F) were determined. The results represent mean \pm standard deviation of 6 animals/group. $\left(^{*}\right) p<$ 0.05 in relation to control and (\#) $p<0.05$ in relation to the other experimental group. 

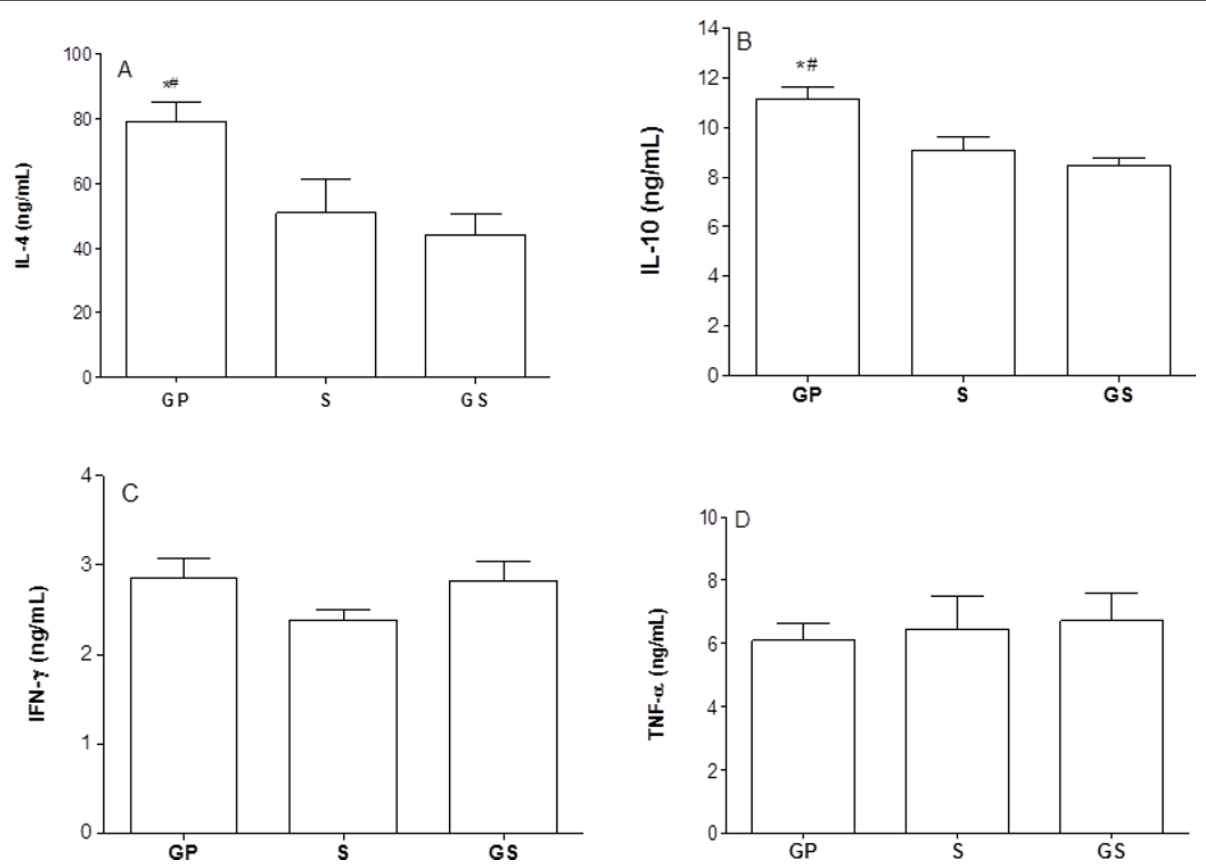

Figure 3 Serum concentration of cytokines. Serum concentration of cytokines in C57BI/6 mice treated with topical oral gel containing propolis (GP) in comparison with the group treated only with the gel base (GS), or with saline (S). ELISA was used to determine the serum concentrations of IL-4 (A); IL-10 (B); IFN- $\gamma(C)$ and TNF- $\alpha$ (D). The results represent mean \pm standard deviation of 6 animals/group. $\left(^{*}\right) p<0.05$ in relation to the control and $(\#) p<0.05$ in relation to the other experimental group.

metabolism as a result of a high population density and their generally higher resistance to antimicrobial agents [43].

Despite the significant in vitro antimicrobial activity of chlorhexidine against $S$. mutans biofilms, its use in dentistry is controversial because of local side effects, which include discoloration of the teeth, tongue, restorations, and dentures; soreness of the oral mucosa; and irritation of taste buds [44].

C. albicans is considered a commensal microorganism, inhabiting the oral mucosa and other anatomic sites. However, in certain situations, this microorganism can cause opportunistic local or systemic infections that are often severe and difficult to control, especially in hosts with specific predisposing factors $[45,46]$. Thus, in addition to being used to control $S$. mutans growth, products formulated from $M$. fasciculata geopropolis might be used as adjuvants for the treatment of oral candidiasis and, ultimately, infections of other mucosa.

Chemical characterization of the extracts studied showed significant differences in the concentration of phenols and flavonoids among samples. The chemical composition of geopropolis produced by stingless bees in Brazil varies according to species. Moreover, available flora further influence the chemical composition of propolis [47]. According to Velikova et al. [6], members of the tribe Meliponini fly short distances and therefore use the first exudate sources that they encounter during their flights.

Only one of the propolis extracts (HAE-1) analyzed failed to show inhibitory activity against the microorganisms tested in this study, a finding that would suggest variations in the chemical composition of this sample. However, preliminary chemical analysis performed did

Table 3 Effect of topical oral treatment with a gel based on geopropolis (GP) from Melipona fasciculata Smith on organ weight in mice.

\begin{tabular}{|c|c|c|c|c|c|c|}
\hline \multirow[t]{2}{*}{ Groups } & \multirow[t]{2}{*}{ Final Weight (g) } & \multirow[t]{2}{*}{ Delta Weight } & \multicolumn{4}{|c|}{ Organ weights (g) } \\
\hline & & & Spleen & Kidney & Stomach & Liver \\
\hline GP & $25 \pm 4$ & 0.2 & $0.08 \pm 0.01$ & $0.16 \pm 0.03$ & $0.42 \pm 0.06$ & $1.3 \pm 0.2$ \\
\hline$S$ & $28 \pm 2$ & -0.2 & $0.10 \pm 0.02$ & $0.18 \pm 0.02$ & $0.33 \pm 0.04$ & $1.6 \pm 0.2$ \\
\hline GS & $27 \pm 2$ & -0.2 & $0.09 \pm 0.01$ & $0.17 \pm 0.01$ & $0.55 \pm 0.08^{*}$ & $1.5 \pm 0.2$ \\
\hline
\end{tabular}

* $p<0.05$ (ANOVA, followed by Tukey's test.) 
Table 4 Histopathological analysis of the tongue in mice that received topical oral treatment with a gel based on geopropolis (GP) from Melipona fasciculata Smith.

\begin{tabular}{lccc}
\hline Parameters Analyzed $^{\mathbf{a}}$ & \multicolumn{3}{c}{ Treatment groups $^{\mathbf{b}}$} \\
\cline { 2 - 4 } & $\mathrm{GP}$ & $\mathrm{S}$ & $\mathrm{GS}$ \\
\hline Vascular Congestion & $0.4 \pm 0.1^{* \#}$ & $1.8 \pm 0.2^{\mathrm{b}}$ & $1.6 \pm 0.1$ \\
Edema & 0 * $^{*}$ & $1.2 \pm 0.2$ & $0.4 \pm 0.1^{*}$ \\
Inflammatory Infiltrate & $0.2 \pm 0.1^{*}$ & $1.2 \pm 0.1$ & $0^{*}$ \\
Hemorrhage & $0.4 \pm 0.1^{*}$ & $2.2 \pm 0.2$ & $0.4 \pm 0.1^{*}$ \\
\hline
\end{tabular}

(a) Tissue changes were scored as: 0 for absent, 1 for scarce, 2 for moderate and 3 for intense. Data represent the mean \pm SEM of 6 animals per group

(b) GP - gel with geopropolis; GS - gel base and S - Saline

(*) $\mathrm{p}<0.05$ in relation to GP

(\#) $\mathrm{p}<0.05$ in relation to $S$

not permit clear demonstration of such variation. Differences in its chemical content may have been influenced by its ecosystem because it originated in a savannah area, whereas HAE-2 and HAE-3 were prepared with geopropolis from an ecosystem whose vegetation comprised mangrove swamps, floodplains, lakes, and babassu palm forests.

Qualitative and quantitative differences in the composition of propolis have an important influence on its biological activity [48]. Among biologically active substances present, flavonoids are the main group contributing to the antimicrobial effects observed [21,49]. In this study, HAE-2 displayed the highest antimicrobial activity and had the greatest flavonoid concentration. Although the antimicrobial action of flavonoids is still controversial and conflicting results have been reported because of inter- and intra-assay variations in susceptibility tests, a link between flavonoids and inhibitory activity on microorganisms has been consistently demonstrated [50]. The antimicrobial activities observed here may be a product of high flavonoid concentration or, as reported for propolis produced by other bee species, a result of a synergistic action between flavonoids and other compounds present in these extracts $[6,13]$.

Although some studies have reported cases of hypersensitivity reactions to Apis propolis $[51,52]$, it is widely accepted that propolis does not present toxic effects $[53,54]$, which confirms the results obtained with geopropolis in our study, since no macro and microscopic changes were detected in organs, which could indicate toxicity of the geopropolis-based gel on the mice.

Moreover, among the biochemical parameters studied, only an increase in the urea concentration was detected, but within the normal range for mice $(41,97 \mathrm{mg} / \mathrm{dl}$ to $60,02 \mathrm{mg} / \mathrm{dl}$ ), which does not indicate renal toxicity[55]. In fact, compounds like flavonoids, caffeic acid, and their esters present in propolis appear to prevent against membrane fragility in organs such liver and kidney, decreasing the level of urea and the leakage of liver enzymes into the circulation $[54,56,57]$.

The reduction observed in the levels of cholesterol and triglycerides can be associated to the presence of antioxidants and flavonoids. Apparently, these compounds can act as inhibitors of lipid peroxidation (LPO) by scavenging polyunsaturated fatty acids' peroxy radicals and interrupt the chain reactions [58].

Despite not having shown signs of toxicity, the increased production of IL-4 and IL-10, cytokines associated with a Th2 response, suggests an anti-inflammatory activity for the product [59]. In fact, the histopathological assessment of the tongue corroborates these data, since tissue changes were significantly lower in the GP group, possibly because of the anti-inflammatory effects of the geopropolis. Tissue alterations in the other animal groups were probably resulting from their manipulation at the time of treatment and/or collection of the material.

The immunomodulatory effect displayed has been previously reported in investigations with Apis propolis [4,60-63]. However, we did not find any reports describing the effects of geopropolis from native bees on the production of cytokines, specifically IL-4 and IL-10.

The potential use of propolis (or geopropolis) in dentistry is promising not only due to its antimicrobial activity against oral pathogens, but also due to its other biological and pharmacological properties, which include anti-inflammatory, antitumor, antioxidant, hematostimulative, and immunomodulatory properties $[2,4,64,65]$. In addition, it is considered relatively non-toxic [21,22].

\section{Conclusions}

In conclusion, our data indicate that geopropolis produced by $M$. fasciculata can exhibit antimicrobial activity against $S$. mutans and $C$. albicans. The activity against $S$. mutans was confirmed by further demonstrating the antibacterial effect of one extract on biofilm viability. The extract with the highest flavonoid concentration, HAE-2, displayed the highest antimicrobial activity. The gel maintained the antibacterial activity previously demonstrated in the geopropolis extract against $S$. mutans. Furthermore, no toxic effects were detected in mice treated with GP. On the other hand, an immunomodulatory action, due to the increase of anti-inflammatory cytokines, was observed. Our data demonstrate that geopropolis has the potential to be used for the control or prevention of diseases of the oral cavity, especially caries and candidiasis, as well as for treatment of inflammatory processes.

\section{List of Abbreviations}

HAE: Hydroalcoholic extracts of geopropolis; MBC: Minimum bactericidal concentration; HAE-2-CF: Chloroform fraction of hydroalcoholic extract No. 2 
of geopropolis; HAE-2-HF: Hexane fraction of hydroalcoholic extract No. 2 of geopropolis; BHI: Brain-Heart Infusion; ATCC: American Type Culture Collection; CFU: Colony-forming unit; PBS: Phosphate-buffered saline.

\section{Acknowledgements}

The authors wish to thank the Conselho Nacional de Desenvolvimento Científico e Tecnológico (CNPq) and the Banco do Nordeste for financial support and the Fundação de Amparo a Pesquisa e ao Desenvolvimento Científico e Tecnológico do Maranhão (FAPEMA) for the fellowship support.

\section{Author details}

'Laboratório de Imunofisiologia, Universidade Federal do Maranhão, Av. dos Portugueses, SN, CEP: 65.080-040, São Luís, Maranhão, Brazil. ${ }^{2}$ Departamento de Odontologia, Universidade Federal do Maranhão, Av. dos Portugueses, SN, CEP: 65.080-040, São Luís, Maranhão, Brazil. ${ }^{3}$ Laboratório de Microbiologia, Universidade Federal do Maranhão, Av. dos Portugueses, SN CEP: 65.080-040, São Luís, Maranhão, Brazil. "Laboratório de Farmacognosia, Universidade Federal do Maranhão, São Luís, Av. dos Portuqueses, SN, CEP: 65.080-040, Maranhão, Brazil. ${ }^{5}$ Laboratório de Microbiologia, Centro Universitário do Maranhão, Rua Josué Montello No. 1, CEP: 65.075-120, São Luís, Maranhão, Brazil.

\section{Authors' contributions}

SAL prepared the extracts, carried out the microbiological evaluation, organized the data analysis and drafted the manuscript. ALAP assisted with the data analysis and helped draft the manuscript. RPD carried out the chemical characterization and partitioned the extracts. ASR collected the geopropolis samples and helped with preparation of extracts. MJAMA helped with preparation of geopropolis extracts and animal experimental procedures. NSM helped with animal experimental procedures. LAS carried out histopathological analysis. MNSR participated in chemical characterization and helped draft the manuscript. FRFN helped with data analysis and manuscript revision. RNMG conceived the study, participated in its design and coordination, and critically reviewed the manuscript for important intellectual content. VMN conceived the study, coordinated the microbiological assays, and was involved in drafting the manuscript and revising it critically for intellectual content. All authors read and approved the manuscript.

\section{Competing interests}

The authors declare that they have no competing interests.

Received: 23 June 2011 Accepted: 4 November 2011 Published: 4 November 2011

\section{References}

1. Ghisalberti EL: Propolis: A review. Bee World 1979, 60:59-84

2. Banskota AH, Tezuka Y, Adnyana IK, Midorikawa K, Matsushige K, Message D, Huertas AA, Kadota S: Cytotoxic, hepatoprotective and free radical scavenging effects of propolis from Brazil, Peru, the Netherlands and China. J Ethnopharmacol 2000, 72(1-2):239-246.

3. Dobrowolski JW, Vohora SB, Sharma K, Shah SA, Naqvi SA, Dandiya PC: Antibacterial, antifungal, antiamoebic, antiinflammatory and antipyretic studies on propolis bee products. J Ethnopharmacol 1991, 35(1):77-82.

4. Sforcin JM: Propolis and the immune system: a review. J Ethnopharmacol 2007, 113(1):1-14.

5. Bankova V: Chemical diversity of propolis and the problem of standardization. J Ethnopharmacol 2005, 100(1-2):114-117.

6. Velikova M, Bankova V, Marcucci MC, Tsvetkova I, Kujumgiev A: Chemical composition and biological activity of propolis from Brazilian meliponinae. Z Naturforsch [C] 2000, 55(9-10):785-789.

7. Pereira AL, Bicalho B, Aquino-Neto FR: Comparison of propolis from Apis mellifera and Tetragonisca angustula. Apidologie 2003, 34:291-298.

8. Bankova V, Popova M: Propolis of stingless bees: a promising source of biologically active compounds. Pharmacog Rev 2007, 1(1):88-92.

9. Roubik D: Ecology and Natural History of Tropical Bees. Cambridge: Cambridge Univ. Press; 1989.

10. Kerr WE: Biologia e manejo da tiúba: a abelha do Maranhão. São Luís, MA: EDUFMA; 1996.

11. Castaldo S, Capasso F: Propolis, an old remedy used in modern medicine. Fitoterapia 2002, 73(Suppl 1):S1-6.
12. Quezada-Euan JJG, de Jesus May-ltza W, Gonzalez-Acereto JA: Meliponiculture in Mexico: problems and perspectives for development. Bee World 2001, 82:160-167.

13. Kujumgiev A, Tsvetkova I, Serkedjieva Y, Bankova V, Christov R, Popov S: Antibacterial, antifungal and antiviral activity of propolis of different geographic origin. J Ethnopharmacol 1999, 64(3):235-240.

14. Farnesi AP, Aquino-Ferreira R, De Jong D, Bastos JK, Soares AE: Effects of stingless bee and honey bee propolis on four species of bacteria. Genet Mol Res 2009, 8(2):635-640.

15. Uzel A, Sorkun K, Oncag O, Cogulu D, Gencay O, Salih B: Chemical compositions and antimicrobial activities of four different Anatolian propolis samples. Microbiol Res 2005, 160(2):189-195.

16. Ikeno K, Ikeno T, Miyazawa C: Effects of propolis on dental caries in rats. Caries Res 1991, 25(5):347-351.

17. Koo H, Gomes BP, Rosalen PL, Ambrosano GM, Park YK, Cury JA: In vitro antimicrobial activity of propolis and Arnica montana against oral pathogens. Arch Oral Biol 2000, 45(2):141-148.

18. Liberio SA, Pereira AL, Araujo MJ, Dutra RP, Nascimento FR, MonteiroNeto V, Ribeiro MN, Goncalves AG, Guerra RN: The potential use of propolis as a cariostatic agent and its actions on mutans group streptococci. J Ethnopharmacol 2009, 125(1):1-9.

19. Park YK, Koo MH, Abreu JA, Ikegaki M, Cury JA, Rosalen PL: Antimicrobial activity of propolis on oral microorganisms. Curr Microbiol 1998, 36(1):24-28.

20. Sawaya ACHF, Souza KS, Marcucci MC, Cunha IBS, Shimizu MT: Analysis of the composition of Brazilian propolis extracts by chromatography and evaluation of their in vitro activity against gram-positive bacteria. Braz $\mathrm{J}$ Microbiol 2004, 35(1-2):104-109.

21. Burdock GA: Review of the biological properties and toxicity of bee propolis (propolis). Food Chem Toxicol 1998, 36(4):347-363.

22. Jasprica I, Mornar A, Debeljak Z, Smolcic-Bubalo A, Medic-Saric M, Mayer L, Romic Z, Bucan K, Balog T, Sobocanec S, et al: In vivo study of propolis supplementation effects on antioxidative status and red blood cells. J Ethnopharmacol 2007, 110(3):548-554

23. Mani F, Damasceno HCR, Novelli ELB, Martins EAM, Sforcin JM: Propolis: Effect of different concentrations, extracts and intake period on seric biochemical variables. J Ethnopharmacol 2006, 105:95-98.

24. Mohammadzadeh S, Shariatpanahi M, Hamedi M, Ahmadkhaniha R Samadi N, Ostad SN: Chemical composition, oral toxicity and antimicrobial activity of Iranian propolis. Food Chem 2007, 103:1097-1103.

25. Moreno MIN, Zampini IC, Ordóñez RM, Jaime GS, Vattuone MA, Isla Ml: Evaluation of the cytotoxicity, genotoxicity, mutagenicity, and antimutagenicity of propolis from Tucuman, Argentina. J Agric Food Chem 2005, 53:8957-8962.

26. Ahuja A, (ed.): Handbook of Bioseparations New York: Academic Press; 2000.

27. Ferro VA, Bradbury F, Cameron P, Shakir E, Rahman SR, Stimson WH: In vitro susceptibilities of Shigella flexneri and Streptococcus pyogenes to inner gel of Aloe barbadensis Miller. Antimicrob Agents Chemother 2003, 47(3):1137-1139.

28. Koo H, Rosalen PL, Cury JA, Ambrosano GM, Murata RM, Yatsuda R, Ikegaki M, Alencar SM, Park YK: Effect of a new variety of Apis mellifera propolis on mutans Streptococci. Curr Microbiol 2000, 41(3):192-196.

29. Curran TM, Ma Y, Rutherford GC, Marquis RE: Turning on and turning off the arginine deiminase system in oral streptococci. Can J Microbiol 1998, 44:1078-1085.

30. Koo H, Pearson SK, Scott-Anne K, Abranches J, Cury JA, Rosalen PL, Park YK, Marquis RE, Bowen WH: Effects of apigenin and tt-farnesol on glucosyltransferase activity, biofilm viability and caries development in rats. Oral Microbiol Immunol 2002, 17(6):337-343.

31. Koo H, Rosalen PL, Cury JA, Park YK, Bowen WH: Effects of compounds found in propolis on Streptococcus mutans growth and on glucosyltransferase activity. Antimicrob Agents Chemother 2002, 46(5):1302-1309.

32. Enríquez A, Prieto E, De Los Ríos E, Ruiz S: Estudio farmacognóstico y fitoquímico del rizoma de Zingiber officinale Roscoe "Jengibre" de la ciudad de Chanchamayo - Región Junín. Perú. Rev Med Vallejiana 2008, 5(1):50-64.

33. Woisky RGR, Salatino A: Analysis of propolis: some parameters and procedures for chemical quality control. J Apic Res 1998, 37:99-105.

34. Matos FJA: Introdução à Fitoquímica Experimental. Fortaleza: UFC i, 32009. 
35. Brazil: Instrução Normativa $\mathrm{n}^{\circ} \mathbf{3}$, de 19 de janeiro de 2001 . Aprova os regulamentos Técnicos de Identidade e Qualidade de Apitoxina, Cera de Abelha, Geléia Real, Geléia Real Liofilizada, Pólen Apícola, Própolis e Extrato de Própolis, conforme consta dos Anexos desta Instrução Normativa.Edited by: Ministério da Agricultura PedA. Brasília DF: Diário Oficial da União; 2001:18

36. Alencar SM, Oldoni TL, Castro ML, Cabral IS, Costa-Neto CM, Cury JA, Rosalen $\mathrm{PL}$, Ikegaki M: Chemical composition and biological activity of a new type of Brazilian propolis: red propolis. J Ethnopharmacol 2007, 113(2):278-283.

37. Steinberg D, Kaine G, Gedalia I: Antibacterial effect of propolis and honey on oral bacteria. Am J Dent 1996, 9(6):236-239.

38. Koru O, Toksoy F, Acikel CH, Tunca YM, Baysallar M, Uskudar Guclu A, Akca E, Ozkok Tuylu A, Sorkun K, Tanyuksel M, et al: In vitro antimicrobial activity of propolis samples from different geographical origins against certain oral pathogens. Anaerobe 2007, 13(3-4):140-145.

39. Loesche WJ: Role of Streptococcus mutans in human dental decay. Microbiol Rev 1986, 50(4):353-380

40. Marsh PD: Microbiologic aspects of dental plaque and dental caries. Dent Clin North Am 1999, 43(4):599-614.

41. van Houte J: Role of micro-organisms in caries etiology. J Dent Res 1994 73(3):672-681.

42. Duailibe SA, Goncalves AG, Ahid FJ: Effect of a propolis extract on Streptococcus mutans counts in vivo. J Appl Oral Sci 2007, 15(5):420-423.

43. Duarte $S$, Rosalen PL, Hayacibara MF, Cury JA, Bowen WH, Marquis RE, Rehder VL, Sartoratto A, Ikegaki M, Koo H: The influence of a novel propolis on mutans streptococci biofilms and caries development in rats. Arch Oral Biol 2006, 51(1):15-22.

44. Twetman S: Antimicrobials in future caries control? A review with special reference to chlorhexidine treatment. Caries Res 2004, 38(3):223-229.

45. Apkan A, Morgan R: Oral candidiasis. J Postgrad Med 2002, 78:455-459.

46. Samaranayake LP: Oral candidosis: an old disease in new guises. Dent Update 1990, 17(1):36-38.

47. Freitas MO, Ponte FAF, Lima MAS, Silveira ER: Flavonoids and Triterpenes from the Nest of the Stingless Bee Trigona spinipes. J Braz Chem Soc 2008, 19(3):532-535.

48. Katircioglu $H$, Mercan N: Antimicrobial activity and chemical compositions of Turkish propolis from different regions. Afr J Biotechnol 2006 5:1151-1153.

49. Russo A, Longo R, Vanella A: Antioxidant activity of propolis: role of caffeic acid phenethyl ester and galangin. Fitoterapia 2002, 73(Suppl 1): s21-29.

50. Cushnie TPT, Lamb AJ: Antimicrobial activity of flavonoids. Int J Antimicrob Agents 2005, 26(5):343-356.

51. Callejo A, Armentia A, Lombardero M, Asensio T: Propolis, a new beerelated allergen. Allergy 2001, 56(6):579.

52. Walgrave SE, Warshaw EM, Glesne LA: Allergic contact dermatitis from propolis. Dermatitis 2005, 16:209-215.

53. Bhadauria M, Nirala SK, Shukla S: Multiple treatment of propolis extract ameliorates carbon tetrachloride induced liver injury in rats. Food Chem Toxicol 2008, 46:2703-2712.

54. Ozen S, Akyol O, Iraz M, Sogut S, Ozugurlu F, Ozyurt H, Odaci E, Yildirim Z Role of caffeic acid phenethyl ester, an active component of propolis, against cisplatin-induced nephrotoxicity in rats. J Appl Toxicol 2004, 24:27-35.

55. Almeida AS, Faleiros ACG, Teixeira DNS, Cota UA, Chica JEL: Reference values for blood-based biochemical parameters in BALB/C and C57BL/6 wild-type mice. Jornal Brasileiro Patol Med Lab 2008, 44(6):429-432.

56. Amin A, Hamza AA: Hepatoprotective effects of Hibiscus, Rosmarinus and Salvia on azathioprine-induced toxicity in rats. Life Sciences 2005 , 77:266-278.

57. Suja SR, Latha PG, Pushpangandan P, Rajasekharan S: Evaluation of hepatoprotective effects of Helminthostachys zeylanica (L) Hook against carbon tetrachloride induced liver damage in Wistar rats. $J$ Ethnopharmacol 2004, 92:61-66.

58. Pascual C, Gonzalez R, Torricella R: Scavenging action of propolis extract against oxygen radicals. J Ethnopharmacol 1994, 41:9-13

59. Wan YY, Flavell RA: The roles for cytokines in the generation and maintenance of regulatory T cells. Immunol Rev 2006, 212:114-130.

60. Khayyal MT, El-Ghazaly MA, El-Khatib AS, Hatem AM, De Vries PJF, ElShafei S, Khattab MM: A clinical pharmacological study of the potential beneficial effects of a propolis food product as an adjuvant in asthmatic patients. Fund Clin Pharmacol 2003, 17:93-102.

61. Orsatti CL, Missima F, Pagliarone AC, Bachiega TC, Búfalo MC, Araújo JP Jr, Sforcin JM: Propolis immunomodulatory action in vivo on Toll-Like receptors 2 and 4 expression and on pro-inflammatory cytokines production in mice. Phytother Res 2010, 24(8):1141-1146.

62. Orsi RO, Funari SR, Soares AMVC, Calvi SA, Oliveira SL, Sforcin JM, Bankova $\mathrm{V}$ : Immunomodulatory action of propolis on macrophage activation. J Venom AnimToxins 2000, 6(2):205-219.

63. Sforcin JM, Orsi RO, Bankova V: Effect of propolis, some isolated compounds and its source plant on antibody production. $J$ Ethnopharmacol 2005, 98(3):301-305.

64. Ahn MR, Kumazawa S, Hamasaka T, Bang KS, Nakayama T: Antioxidant activity and constituents of propolis collected in various areas of Korea. J Agric Food Chem 2004, 52(24):7286-7292.

65. Orsolic N, Basic I: Antitumor, hematostimulative and radioprotective action of water-soluble derivative of propolis (WSDP). Biomed Pharmacother 2005, 59(10):561-570.

\section{Pre-publication history}

The pre-publication history for this paper can be accessed here: http://www.biomedcentral.com/1472-6882/11/108/prepub

\section{doi:10.1186/1472-6882-11-108}

Cite this article as: Liberio et al:: Antimicrobial activity against ora pathogens and immunomodulatory effects and toxicity of geopropolis produced by the stingless bee Melipona fasciculata Smith. BMC Complementary and Alternative Medicine 2011 11:108.

\section{Submit your next manuscript to BioMed Central and take full advantage of:}

- Convenient online submission

- Thorough peer review

- No space constraints or color figure charges

- Immediate publication on acceptance

- Inclusion in PubMed, CAS, Scopus and Google Scholar

- Research which is freely available for redistribution

Submit your manuscript at www.biomedcentral.com/submit
C) Biomed Central 